\title{
A Research on the Feasibility of Introducing Culture in College English Teaching
}

\author{
Lijing Diao ${ }^{1}$ Huandong Wang ${ }^{2}$ \\ ${ }^{1}$ English Department, Cangzhou Normal University, Cangzhou 061001, Hebei, China \\ ${ }^{2}$ Computer Science Department, Hebei Engineering and Technical College, Cangzhou \\ 061001, Hebei, China
}

\begin{abstract}
It is necessary to fuse cultural factors in College English Teaching. This paper explores the contents and approaches of cultural introduction in college English teaching process by studying the relationship between language and culture, and analyzes the results of the teaching experiment and effect.
\end{abstract}

Keywords: College English Teaching; cultural introduction; contents; approaches; effect

\section{Introduction}

Language teaching is not only language knowledge teaching, but also the cultural knowledge teaching. Whether intercultural teaching is fit into foreign language teaching content is the main criterion to distinguish the traditional foreign language teaching and modern foreign language teaching. However, culture jamming is one of the teaching problems. For a long time, our college English teaching only emphasizes language knowledge teaching and language skill training, and neglect the importance of fusing cultural factors. Cultural misunderstandings become a major obstacle to English learning. So teachers should introduce related cultural knowledge timely and appropriately.

\section{The cultural contents introduced in college English teaching}

Since there is still no cultural syllabus, Professor $\mathrm{Hu}$ Wenzhong divides cultural teaching content into five aspects: language communication, nonverbal communication, communication customs and rituals, social structure and interpersonal relationship, and values ${ }^{[1]}$. Teachers can introduce these cultural contents based on the textbook.

\subsection{Language Communication}

Language communication is the primary means of human communication, including vocabulary, idioms (proverbs, maxims, sayings, etc.), syntax, and discourse.

\subsection{Nonverbal Communication}

Nonverbal Communication is human nonverbal behavior used to express specific feelings and thoughts, including facial expression, eye contact, gestures, sound, costumes, etc. The differences between the East and the West in Nonverbal Communication are an obstacle to the communication, resulting in embarrassment, and even misleading. Chinese generally think that British and American people have too many gestures, and their facial expressions are too rich. 
The British and American people may feel that the Chinese people are not willing to expose their emotions, and seem to be unpredictable.

\subsection{Communication customs and rituals}

Communication customs and rituals are rules or habits which human abides in specific communicative activities such as greeting, praising, visiting friends and giving gifts. For example, giving good advice to each other between acquaintances or friends to express care and friendship is an accustomed behavior in Chinese culture. But if you said something to the British and American people like this, they would not appreciate it but feel angry. Because the British and American people have a strong sense of independence, they would think you had spoke to him in a tone like elders.

\subsection{Social structure and interpersonal relationships}

Social structure and interpersonal relationships are a variety of relationships formed in the social sphere, including the relationship among the family, relatives, friends and colleagues. There are also big differences in this aspect between the East and the West. Chinese people believe that if someone is in trouble all should help him, but British and American people are advocate respect for the individual and family privacy ${ }^{[2]}$.

\subsection{Values}

Values are perceptions and attitudes to the state, the collective, nature, knowledge and money. The differences between China Western English-speaking countries in cultural values are obvious. In China Individualism is often regarded as a derogatory term as opposed to the collectivism while in Western countries individualism is linked to enterprising, cherishing individual rights and the spirit of personal struggle and be regarded as the positive attitudes to deal with things ${ }^{[3]}$.

\section{Approaches to introduce culture in College English teaching}

\subsection{Explain the cultural connotations of words and phrases}

There are a large number of words and phrases with rich cultural connotations in English and Chinese. Cultural factors determine the social connotations of the vocabulary and restrict its appropriateness. Whenever teachers encounter different cultural connotations of vocabulary in English and Chinese, we should seize the opportunity to remind students.

\subsection{Contrast Chinese culture with Western culture}

Contrast is a very important means of cross-cultural language teaching. Comparison makes identification. Only by comparison may by comparing find the similarities and differences in language structure and culture between their native language and the target language, which may result in cultural sensitivity in cross-cultural exchange.

\subsection{Introduce allusions}

Most people often quote something like a person or a thing in history, legends, literature or religion in speaking and writing. The person or thing is allusion. The use of allusions can not only make our language colorful, vivid and clear and make it easier to communicate. Many texts quote allusions from literature and the Bible. Students are not familiar with these allusions, so teachers should explain them carefully. 


\section{The teaching effect of introducing culture in College English teaching}

In order to have a better understanding of culture introduction in college English teaching, we have questioned and tested 200 students in our university on language and culture. The pass rate is only $25 \%$. The performance analysis shows that the students' communicative ability and socio-cultural capacity are far below their language ability.

According to the status quo we put forward the strategy of introducing culture in College English Teaching and carry out teaching reform experiment.
These 200 students are divided into three experimental classes and a nonexperimental class. In the teaching experimental classes we carry out the strategy while in the non-experimental class we adopt the ordinary pedagogy.

After a semester of reform experiment, in order to test the experimental effects we have had an English language and culture test in the experimental classes and non-experimental class at the same time. English language and culture level test results are shown in Table 1. (EC stands for experimental classes while NC stands for the non-experimental class.)

Table 1 Statistical table of English language and culture level test results

\begin{tabular}{|c|c|c|c|c|c|c|}
\hline $\begin{array}{c}\text { Question } \\
\text { number }\end{array}$ & $\begin{array}{c}\text { Kinds of } \\
\text { Questions }\end{array}$ & Value & $\begin{array}{c}\text { Average } \\
\text { Scores of EC }\end{array}$ & $\begin{array}{c}\text { Average } \\
\text { Score of NC }\end{array}$ & $\begin{array}{c}\text { Pass rate } \\
\text { of EC }\end{array}$ & $\begin{array}{c}\text { pass rate } \\
\text { of NC }\end{array}$ \\
\hline I & $\begin{array}{c}\text { situational } \\
\text { dialogues }\end{array}$ & 15 & 12.38 & 7.85 & $83 \%$ & $31.2 \%$ \\
\hline II & $\begin{array}{c}\text { Idiom } \\
\text { Translation }\end{array}$ & 20 & 11.73 & 7.38 & $62.6 \%$ & $19.5 \%$ \\
\hline III & social politics & 20 & 14.31 & 5.25 & $74.4 \%$ & $18.5 \%$ \\
\hline IV & $\begin{array}{l}\text { social customs } \\
\text { English and }\end{array}$ & 15 & 13.50 & 8.13 & $89 \%$ & $56 \%$ \\
\hline V & $\begin{array}{l}\text { American } \\
\text { Literature }\end{array}$ & 10 & 7.54 & 4.28 & $82 \%$ & $47 \%$ \\
\hline VI & $\begin{array}{c}\text { Chapter } \\
\text { comprehension } \\
\end{array}$ & 20 & 16.78 & 13.53 & $90.5 \%$ & $78.5 \%$ \\
\hline Total & & 100 & 78.82 & 48.32 & $81 \%$ & $30.5 \%$ \\
\hline
\end{tabular}

Table 1 shows that the teaching reform has had a significant effect and the students in experimental classes understand and master the language and cultural knowledge much better than those in non-experimental class. Compared the student' achievement before and after the experiment, we can see that the pass rate of non-experimental class increases by $5.5 \%$ while the pass rate of experimental classes increase by $56 \%$ and the scores of the experimental class have been significantly improved. The result shows that the experimental class students' language ability, communicative ability and socio-cultural capability have been greatly improved and the strategy of cultural introduction in College English Teaching has made a good effect.

\section{Conclusion}

Though we have made some progress in the exploration of introducing culture in college English teaching, we have encountered some problems in the 
implementation process because of longterm impact of structural linguistics and the deep-rooted traditional teaching model, and there are still many aspects in the introduction approaches and contents to be improved. We should update teaching concepts and put emphasis on cultural teaching to cultivate students' comprehensive language practical ability to adapt to the teaching requirements.

\section{References}

[1] Wenzhong Hu. Cultural Differences and Foreign Language Teaching. Foreign Language Teaching and Research. 1998, 4: 57-59.

[2] Rong Fu. The Culture Teaching Research in College English Teaching. Journal of Ningbo Institute of Education. 2008, 5: 34-37

[3] Strevens, D. Varieties of English. English Studies. 1983.7:12-14. 